\title{
Petrography, geochemistry and geodynamic environment of potassic alkaline rocks in Eslamy peninsula, northwest of Iran
}

\author{
B Hajalilou ${ }^{1, *}$, M Moayyed ${ }^{2, * *}$ and Gh Hosseinzadeh ${ }^{2}$ \\ ${ }^{1}$ Department of Geology, Payame Noor University, Tabriz, Iran. \\ ${ }^{2}$ Department of Geology, University of Tabriz, Tabriz, Iran. \\ *e-mail: hajalilou@pnu.ac.ir bhshnaha@yahoo.com \\ **e-mail:m.moayyed@tabrziu.ac.ir
}

Eslamy peninsula, $360 \mathrm{~km}^{2}$ in area, is located in the eastern coast of Urmieh lake in the northwest of Iran. This peninsula is a complex stratovolcano with a collapsed center, which is elevated due to later intrusions of sub-volcanic masses with trachytic to microsyenitic composition. The composite cone consists of a sequence of leucite tephrite, tephrite, leucite basanite, basanite and related pyroclastic rocks. Magmatic activities in the Eslamy peninsula begin with potassic alkaline to ultrapotassic and basic, silica-undersaturated shoshonitic rocks and they are followed by intrusions of lamprophyric dykes and end with acidic magmatism including trachytic, microsyenitic, syenitic and phonolitic domes. The original magma of the Eslamy peninsula rocks has a potassic alkaline nature (Roman type) rich in LREE and LILE and depleted of HREE. These characteristics suggest that the origin of magma can be from deep mantle with a garnet lherzolite composition, a low partial melting rate which has been contaminated by crustal materials in its way up. Fractional crystallization of olivine, diopsidic clinopyroxene and leucite played an important role in the evolution of magmas. Scrutinizing the geodynamic environment of Eslamy peninsula rocks in discrimination diagrams indicates that these rocks must have been formed in a post-collision magmatic arc setting.

\section{Introduction}

Potassic igneous rocks are categorized as K-rich calc-alkaline rocks, subduction-related shoshonites, within-plate potassic rocks, orogenic ultrapotassic rocks, shoshonitic and alkaline lamprophyres (Morrison 1980; Muller and Groves 1997). $\mathrm{K}_{2} \mathrm{O} / \mathrm{Na}_{2} \mathrm{O}$ molar ratio in potassic rocks is equal to 1 or a little more and their $\mathrm{MgO}$ content is over than 3\% (Peccerillo 1992; Foley et al 1987). Ultrapotassic rocks have a $\mathrm{K}_{2} \mathrm{O} / \mathrm{Na}_{2} \mathrm{O}$ molar ratio greater than 2 , with the amount of $\mathrm{MgO}$ being lower than 3\% (Foley et al 1987). Nevertheless, the term potassic is usually used for both potassic and ultrapotassic rocks. These rocks are classified into four main groups namely, lamproites, shoshonites and Roman-type potassic, kamafugites, and ultrapotassic rocks.

The following hypothesis have been put forward regarding the petrogenesis of these rocks:

- Assimilation of carbonate rocks by basic magma (Rittman 1933; Peccerillo 1992).

- Local infiltration (Harris 1957).

- Zone melting (Key and Gast 1973).

- Mantle metasomatism (Menzies and Hawkes 1981; Peccerilo 1992; Roy et al 2004).

In general, it is believed that potassic magmas can not be produced by partial melting of the mantle alone and the other factors like inhomogeneous mantle sources metasomatically rich in LILE and LREE are required as well (Peccerillo 1992;

Keywords. Mineralogy; petrology; geochemistry; volcanology; geodynamics; Eslamy peninsula; Iran. 
Foley et al 1987). Peccerillo (1992) believes that the volatiles, LILEs and LREEs are accumulated in hydrous minerals such as phlogopite and apatite that are found in the glimmeritic veins and layers beneath the continental crust in the upper mantle.

Shoshonitic and ultrapotassic magmatism in the Eslamy peninsula with the Pliocene (6.5-8 Ma) age has been reported to occur in the eastern coast of the Urmieh lake (Moin-Vaziri et al 1991; Moradian 1997, 2007). Several assumptions have been made with regard to the petrogenesis of these rocks, some of which are as follows:

- Final stages of magmatism in the active continental margin due to subduction of Neo-Tethys oceanic crust beneath the central Iran block (Moin-Vaziri 1985; Moin-Vaziri et al 1991).

- Magmatism related to continental rift setting (Amidi 1975; Emami 1981; Amidi et al 1984).

- Hot spot-related magmatism within a continental crust (Berberian 1981; Berberian and Berberian 1981).

The evidence discussed in this study indicates that magmatism in the Eslamy peninsula must have occurred in a post-collisional magmatic arc.

\section{Geological setting}

Eslamy peninsula is located in the eastern coast of Urmieh lake (figure 1). This peninsula includes a complex stratovolcano with gentle slope flanks and a collapsed caldera in the central part (Hajalilou and Moayyed 2005). Later intrusion of sub-volcanic trachytic to microsyenitic rocks is supposed to have caused doming and an uplift in the central parts in these sections (figure 2). These rocks are a part of the Tertiary-Quaternary magmatic zone in northwest of Iran. The Eslamy peninsula highlands have their own distinct morphotectonic features, and are separated from the Sahand volcanic rocks by a plain. The gravitational field in this area varies from -110 to -100 milligals and the thickness of the crust is about $42-43 \mathrm{~km}$ (Dehghani and Makris 1983).

The Eslamy peninsula's two main faults trending NNW-SSE and ENE-WSW intersect one another almost in the middle space (figure 2). Furthermore, aerial magnetometry data delineates an important lineament trending NNE-SSW in the basal rocks of the peninsula. This lineament is presumably an extension of either the Arax or the ApsheronPalmira fault extended towards the western coast of the Caspian Sea. The lineament seems to have an important role in the tectonic evolution of the study area.

The Eslamy peninsula stratovolcano is composed of a sequence of leucite basanite to leucite

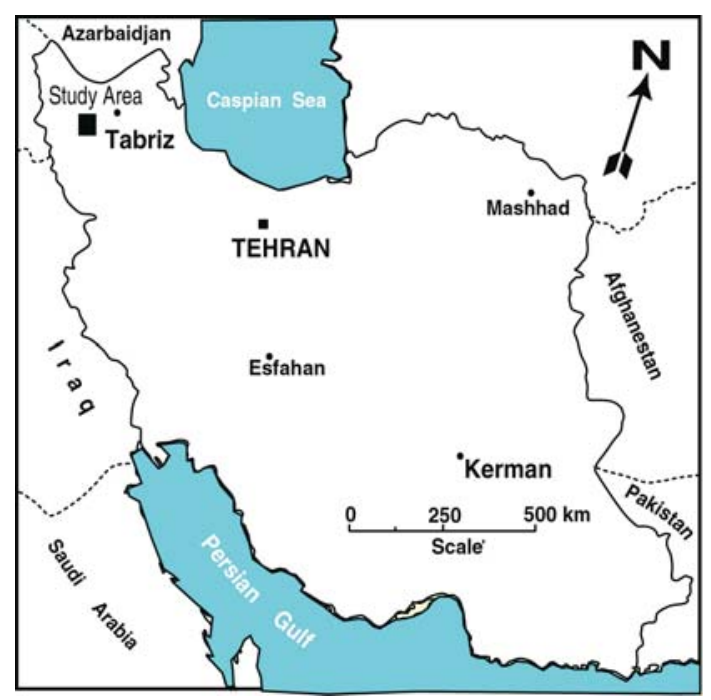

Figure 1. Location of Eslamy peninsula in Iran.

tephrite lavas and the related pyroclastic rocks (breccia and agglomerate). These rocks are cut off by later dykes with composition of basanite and tephrite (figure 3a). The orientation of these dykes is WNW-ESE (figure 2) which implies the extensional mechanism of faults and fractures during later magmatic events of the peninsula. These events have led to the uplifting of the older volcanic units (Hajalilou 2005, 2006). Trachytic to microsyenitic plugs and lamprophyric dykes intersect Pliocene volcanoclastic conglomerate (figure $3 \mathrm{~b}$ ).

\section{Petrography}

The igneous rocks from the Eslamy peninsula are composed of tephrite, basanite, lamprophyre, trachyte, syenite and ultramafic xenoliths, each of which is taken up separately in some detail below.

\subsection{Tephrites}

Tephrites exhibit a porphyritic texture and their distinct phenocrysts are clinopyroxene and leucite. The major minerals of these rocks include euhedral to subhedral clinopyroxene (figure 4a) and idiomorphic crystals of leucite. The chemical composition of clinopyroxenes was identified as diopside to salite $\left(\mathrm{Wo}_{47} \mathrm{En}_{48.5} \mathrm{Fs}_{4.5}\right.$ to $\left.\mathrm{Wo}_{49.3} \mathrm{En}_{36} \mathrm{Fs}_{14.7}\right)$ by EMPA analysis (Moradian 1997). The analyses indicated that the amounts of $\mathrm{MgO}$ and $\mathrm{CaO}$ get reduced from center to margin in zonal diopside phenocrysts, followed by an increase in the amounts of $\mathrm{FeO}, \mathrm{Na}_{2} \mathrm{O}, \mathrm{Al}_{2} \mathrm{O}_{3}, \mathrm{TiO}_{2}$ and $\mathrm{SiO}_{2}$ are increasing. In all diopside phenocrysts the increase of $\mathrm{Al}_{2} \mathrm{O}_{3}$ and $\mathrm{TiO}_{2}$ is accompanied by a decrease in $\mathrm{SiO}_{2}$ (Moradian 1997). These crystals show sieve texture 


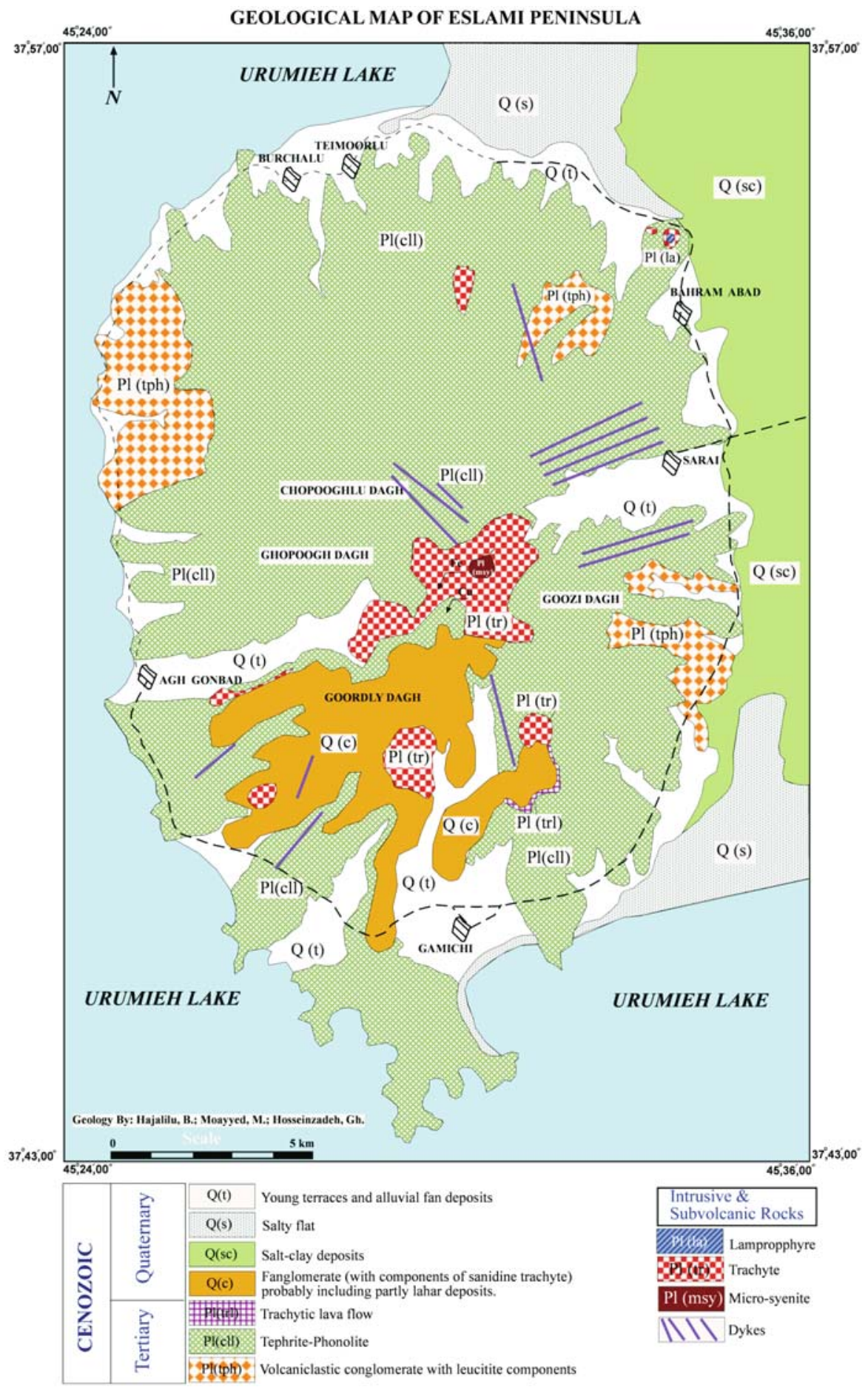

Figure 2. Geological map of Eslamy peninsula.

(figure 4a). Modal data of the Eslamy peninsula igneous rocks is summarized in table 1 .

Leucites are the second most important minerals in tephrites and are seen as euhedral crystals of complex twinning with small needles of apatite and rutile within them. This mineral is altered to analcime and orthoclase. These crystals are low in $\mathrm{Na}_{2} \mathrm{O}$; however, the margins of phenocrysts are rich in $\mathrm{Na}_{2} \mathrm{O}$ which might as a result of an alteration to nepheline and analcime from the margins of these phenocrysts. The $\mathrm{Si} / \mathrm{Al}$ ratio in phenocryst samples varies from 2.03 to 2.06 (Moradian 1997). Minor minerals of these rocks include fewer amounts of plagioclase, sanidine, olivine, biotite, apatite and opaque minerals which are located in hyaline matrix.

Abundance of clinopyroxene and leucite coupled with the lack of hydrous minerals and plagioclase 


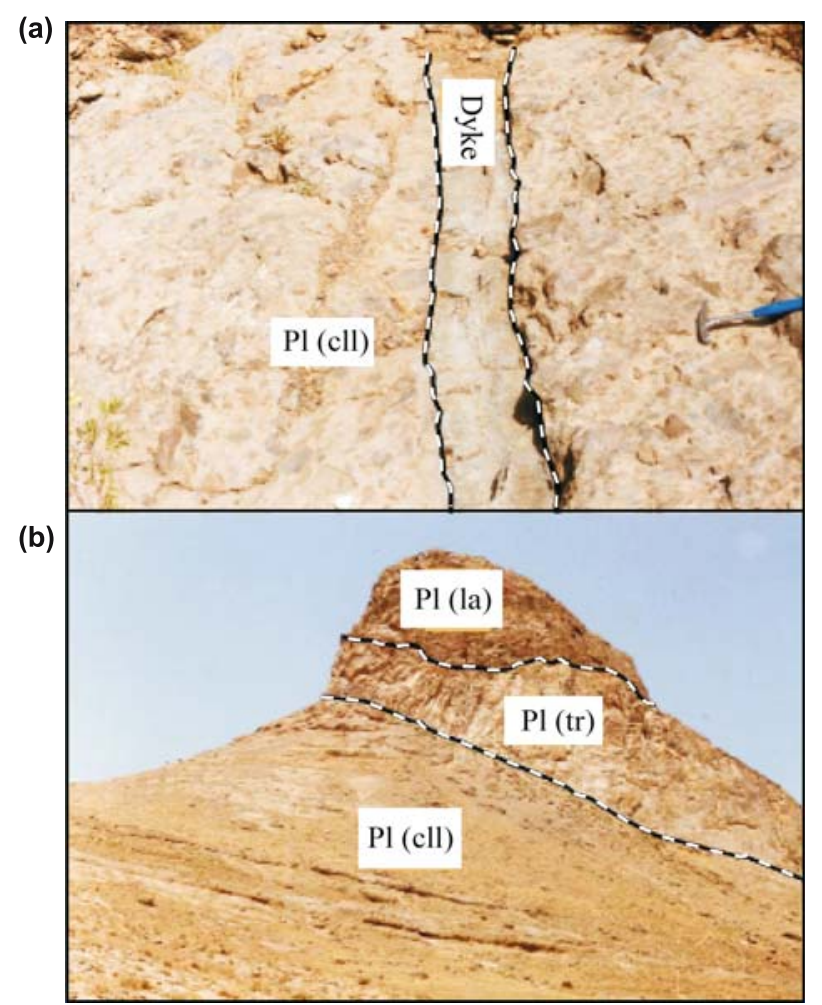

Figure 3. (a) Tephritic-phonolitic dyke intersects volcanoclastic conglomerate. (b) Trachytic plug with lamprophyric head intersects volcanoclastic conglomerate.

show that the crystallization of magma has happened in dry and imbalanced conditions. These rocks basically display hyaloporphyritic to hyalomicrolitic porphyry texture.

\subsection{Basanites}

Basanites mainly consist of euhedral to subhedral clinopyroxene (figure 4b) with the composition varying from diopside to salite $\left(\mathrm{Wo}_{47.5} \mathrm{En}_{49.5}\right.$

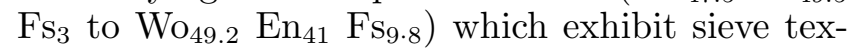
ture and normal zoning. Another major mineral of these lavas is euhedral crystals of leucite with a complex twinning. The third most common mineral of basanites is euhedral olivine (figure $4 \mathrm{~b}$ ) with modal amount of $10 \%$ to $15 \%$. The composition of these crystals ranges from $\mathrm{Fo}_{84}$ to $\mathrm{Fo}_{84.8}$ and do not show any interaction margin. The presence of $\mathrm{CaO}$ is higher than $0.1 \%$ and amount of $\mathrm{TiO}_{2}$, $\mathrm{Al}_{2} \mathrm{O}_{3}, \mathrm{Cr}_{2} \mathrm{O}_{3}$ and $\mathrm{Ni}$ is less than that. The diffusion coefficient of $\mathrm{Mg}$ and $\mathrm{Fe}$ elements in olivine crystals in relation to matrix is $4 \%$ which refers to crystallization of these crystals in high pressure (Moradian 1997). These crystals are basically iddingsitised along crystalline fractures. Minor minerals of basanites are sanidine and magnetite (Hajalilou 2005). Some inclusions of rutile and apatite needles can be seen in leucite. Texture of these rocks is hyaloporphyritic to hyalomicrolitic porphyry.

\subsection{Lamprophyric dykes}

Lamprophyric dykes cut the volcanic rocks (tephrites and basanites) and the related pyroclastics with a NW-SE trend and lie beneath trachyte lavas. These rocks are characterized with euhedral and shiny phenocrysts of mica which can grow up to 3 or $4 \mathrm{~cm}$ and show porphyiric texture. The major minerals are euhedral to subhedral phenocrysts of zonal mica (figure 4c) which are delimited in a fine grain matrix of alkalifeldspar with ocellar texture and fine grain alteration products. Euhedral to subhedral clinopyroxenes are pseudomorphed by the alteration products (calcite and opaque minerals). Minor minerals consist of amorphous apatite phenocrysts (figure 4c) and opaque minerals like pyrrhotite and magnetite. The biotites composition of these dykes is phlogopite (Moayyed et al 2008).

Spider diagrams pattern for the phlogopite is similar to the pattern for the whole rock but Rh, $\mathrm{Ti}, \mathrm{K}$, and Ba contents in the phlogopite are higher than the entire rock and $\mathrm{Zr}, \mathrm{Nd}, \mathrm{P}, \mathrm{Sr}, \mathrm{Ce}, \mathrm{La}, \mathrm{Nb}$ and Th contents are lower than those for the whole rock (Moayyed et al 2008).

\subsection{Trachytes}

Trachytes in the Eslamy peninsula are exposed in three main forms: lava, dyke and subvolcanic domes. Porphyritic texture and sanidine megacrysts which, in some cases, may be as long as $5 \mathrm{~cm}$ can be seen in the samples belonging to dykes and subvolcanic domes. Major minerals include sanidine (figure 4d). The minor minerals are subhedral crystals of clinopyroxene, mica, sphene, apatite and the rarest is plagioclase. Megacrysts of sanidine arranged along the flow direction are present in the samples showing microlitic porphyry texture. The composition of sanidine in these rocks is $\mathrm{Or}_{62.8}$ to $\mathrm{Or}_{72.9}$, and they contain $0-0.15 \% \mathrm{TiO}_{2}, 0-1.77 \%$ $\mathrm{MgO}$ and $0-1.99 \% \mathrm{FeO}$. As $\mathrm{SiO}_{2}$ increases in sanidine crystals, the amount of $\mathrm{K}_{2} \mathrm{O}$ grows larger in accordance with it (Moradian 1997). In trachyte lavas, biotite crystals are recognized by $\mathrm{TiO}_{2}$ and $\mathrm{FeO}$ assembly in their margins and their $\mathrm{Mg} / \mathrm{Mg}+$ $\mathrm{Fe}^{+2}$ ratio is less than 0.67 (Moradian 1977). The absence of amphiboles in trachyte lava is a sign of magma crystallization in dry situations. The textures of trachyte lavas are trachytic, felsitic and intergranular. In the samples, belonging to dykes and subvolcanic domes, the main texture is microlitic porphyry.

\subsection{Syenites}

Syenite to microsyenite masses of Eslamy peninsula, located in the center of this area, are injected 

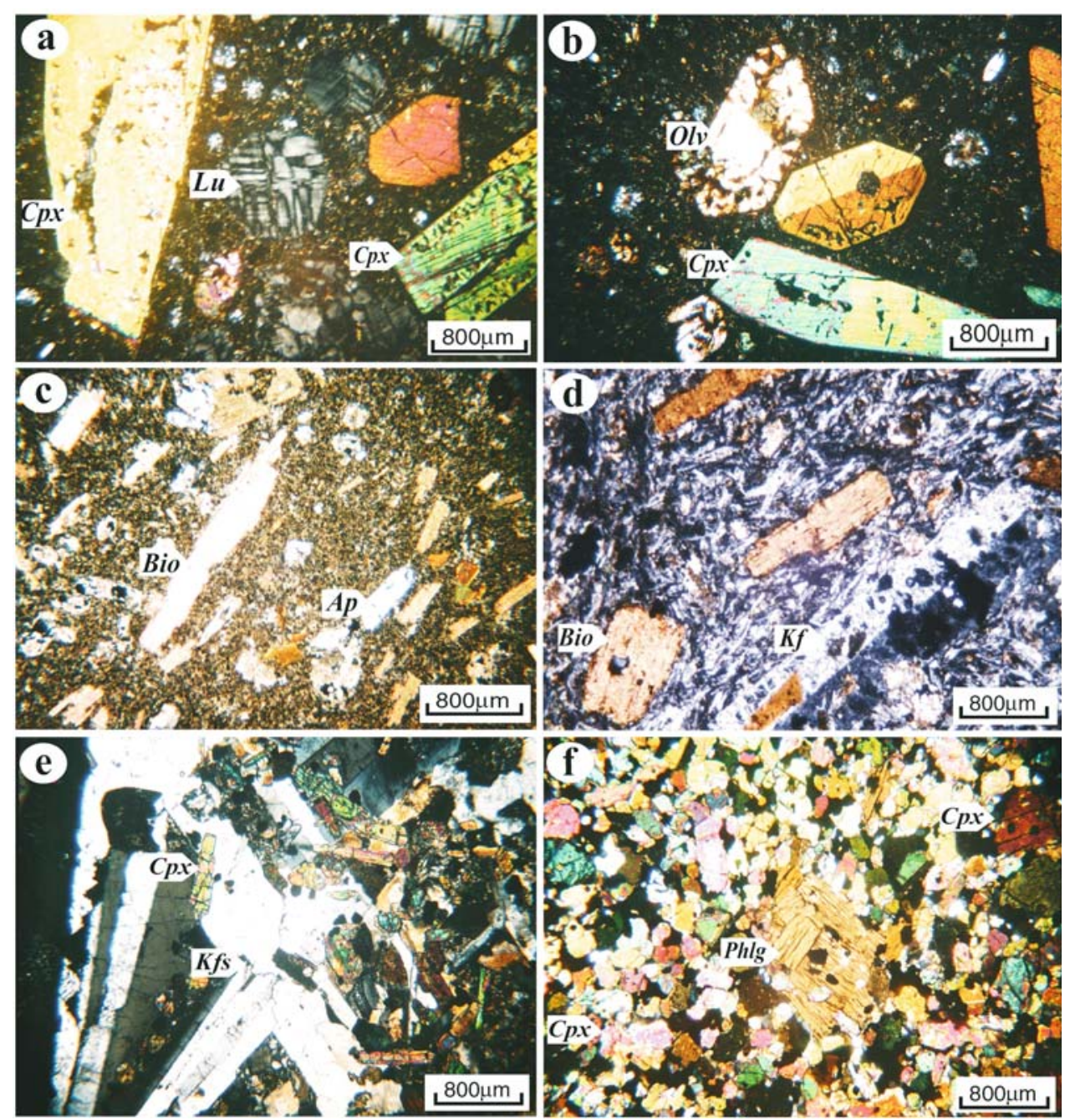

Figure 4. (a) Subhedral clinopyroxene with sieve texture and idiomorphic leucite with complex twinning in tephrites; (b) Euhedral clinopyroxene and olivine in basanite; (c) Subhedral phenocrysts of biotite and apatite in lamprophyric dykes; (d) Phenocrysts of sanidine and trachytic texture in trachyte; (e) Alkalifeldspar and clinopyroxene in syenite; (f) Phenocryst of phlogopite with clinopyroxene in mica clinopyroxenite (mantle xenoliths).

Table 1. Modal composition from the Eslamy peninsula igneous rocks.

\begin{tabular}{lcccccc}
\hline & \multicolumn{6}{c}{ Minerals } \\
\cline { 2 - 7 } Rocks & CPX & Oli. & Lu. & AFs. & Plg. & Bio. \\
\hline Trachyte & + & - & - & + & + & + \\
Syenite & + & - & - & + & - & + \\
Lamprophyre & + & - & - & + & - & + \\
Basanite & + & + & + & + & + & - \\
Tephrite & + & - & + & + & + & + \\
\hline
\end{tabular}

into volcanic and pyroclastic rocks (tephrites, basanites and tuffs) and to the related pyroclastics. The major minerals are subhedral phenocrysts of alkalifeldspar and clinopyroxenes, biotite (figure 4e), sphen, apatite and opaque minerals are minor ones. The dominant texture of the mass is granular to trachytoide.

\subsection{Clinopyroxenites with mica (ultramafic xenoliths)}

These xenoliths can be seen in leucite tephrite to leucite basanite dykes and lavas as circular to ellipsoidal forms. Their color in hand specimen is olive to dark green. The major minerals in these rocks are euhedral to subhedral clinopyroxene, phlogopite and opaque (figure 4f). Phlogopite shows kink banding. These rocks must have originated as mantle xenoliths.

\section{Analytical methods}

Thirtyone specimens of various rock types were chosen to be analyzed for petrochemical and geodynamic studies. These specimens were sent to the Kansaran Binalood Company for XRF analysis (table 2). A Phillips PW-1480 X-Ray fluorescense 


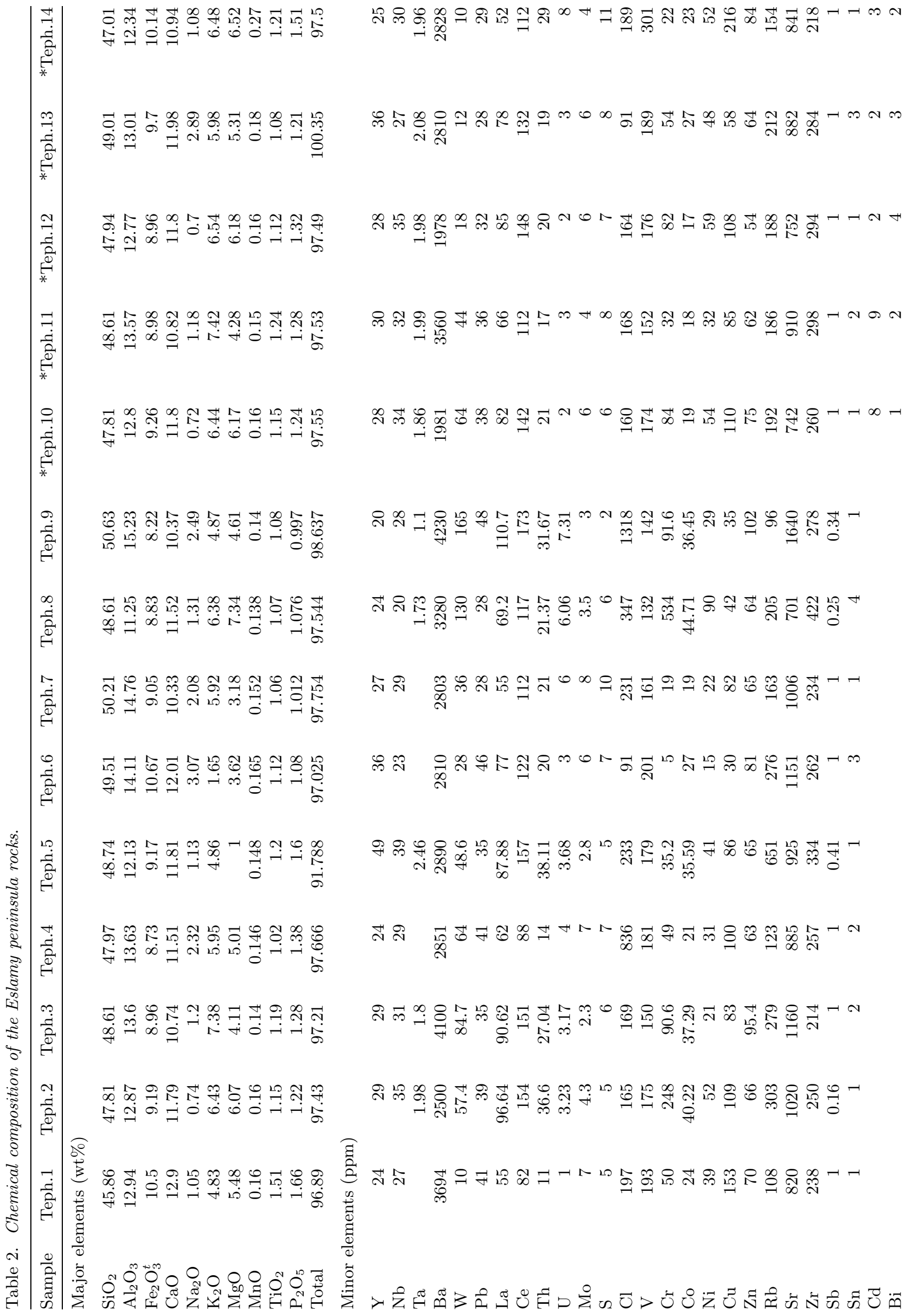




\section{$-\stackrel{\Re}{\sim} \underset{\sim}{\stackrel{N}{N} \infty}$

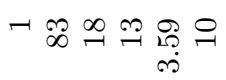 \\ $\neg \stackrel{\infty}{\sim} \stackrel{\sim}{\sim} \underset{\infty}{\infty} \infty$ \\ $\neg$ ํำ

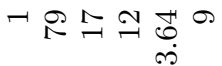

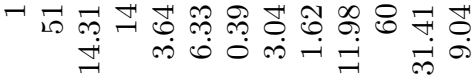

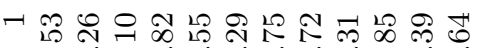

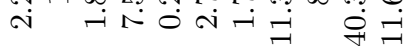

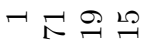

$\neg \cong$

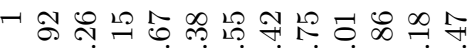

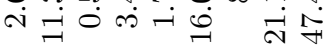

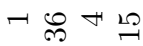

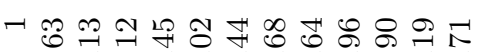

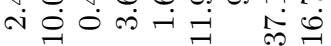

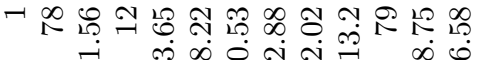
$\infty$

$\neg \mathfrak{ఠ}$

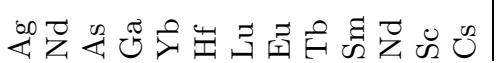

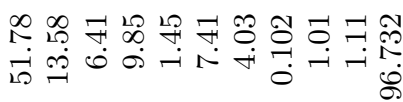

초

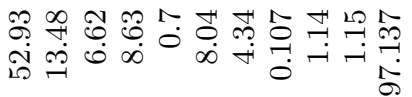

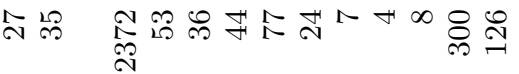

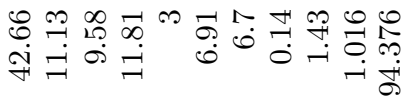

乎

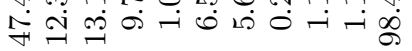

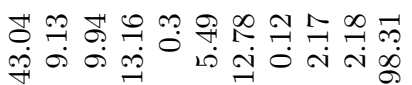

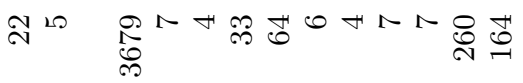

จำ $\infty$ 央

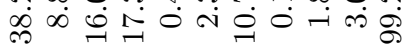

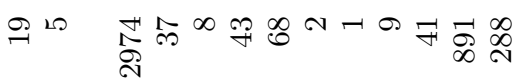

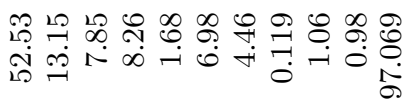

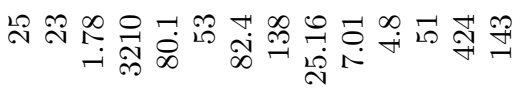

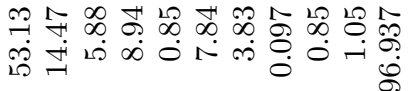

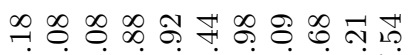

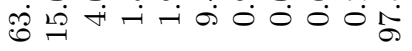

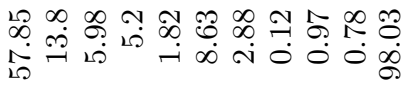

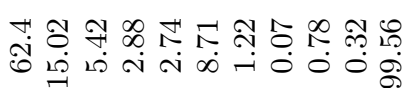

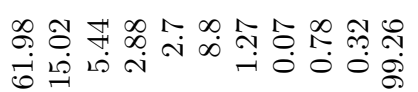

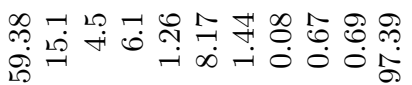

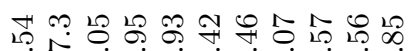

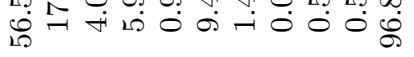

L

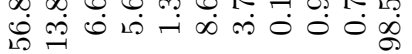

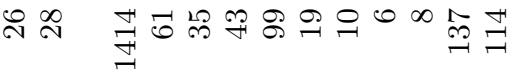

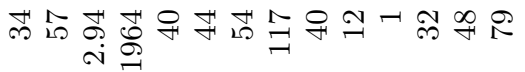

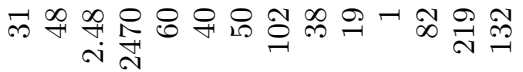

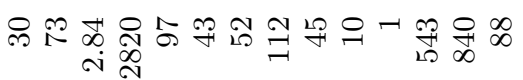

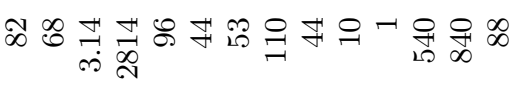

아 우

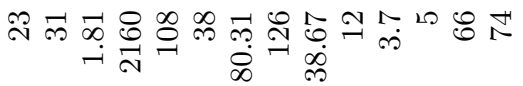

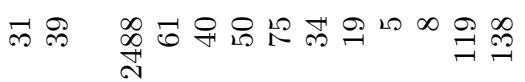

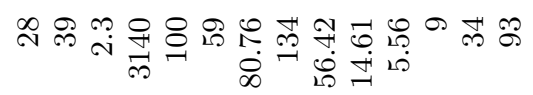

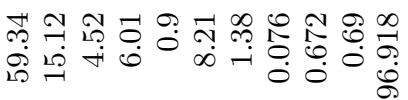

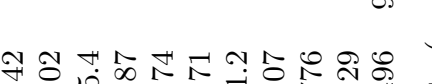
तु

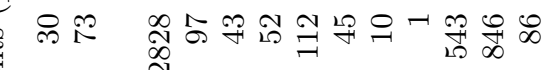

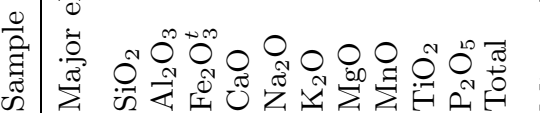

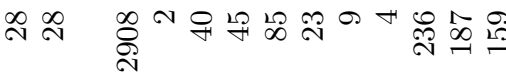

ำ 


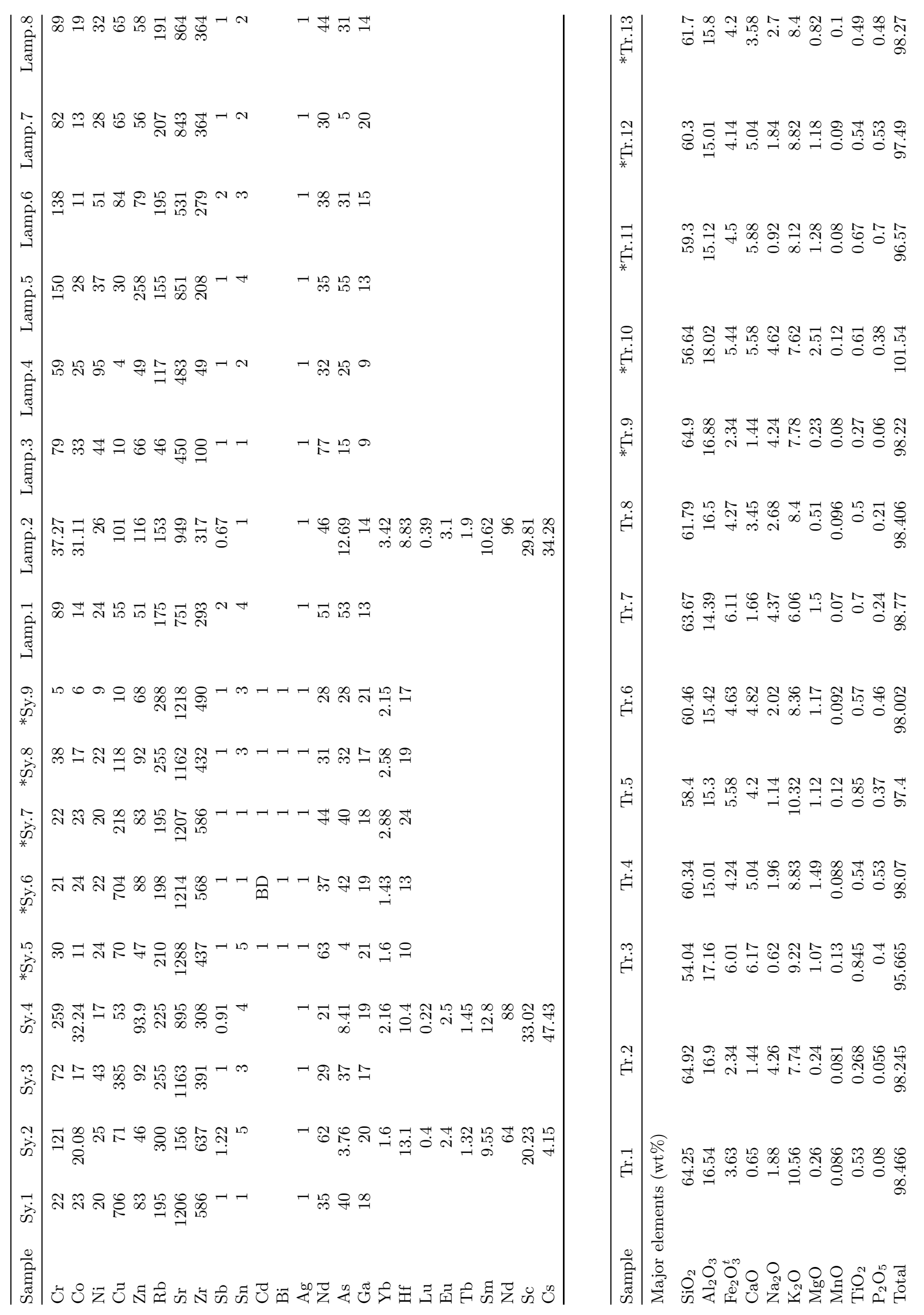




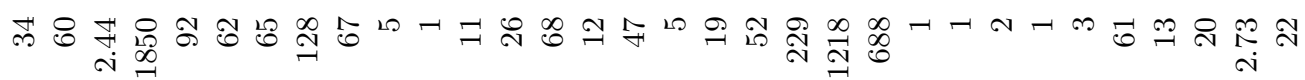

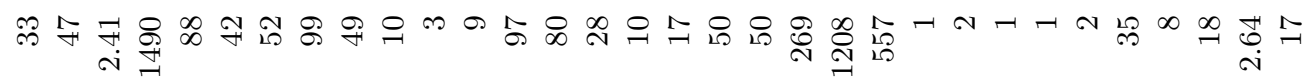

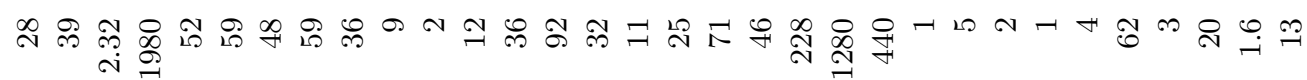

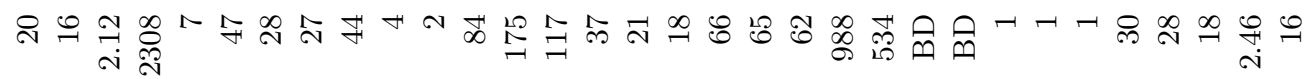

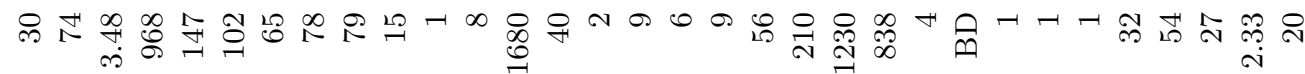

مิ

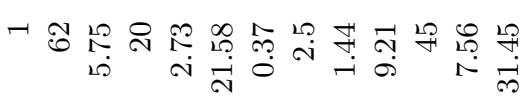

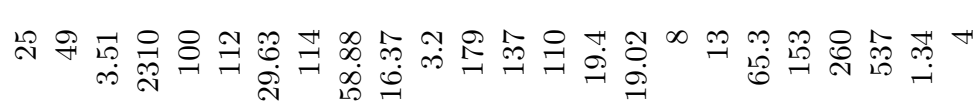

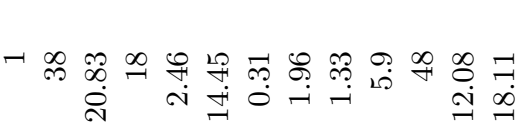

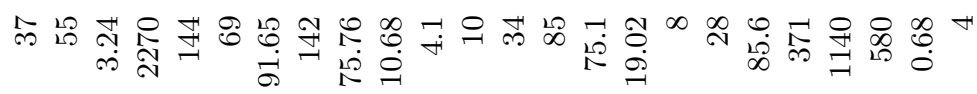

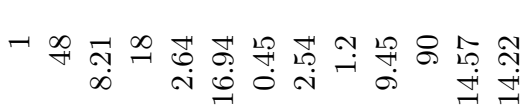

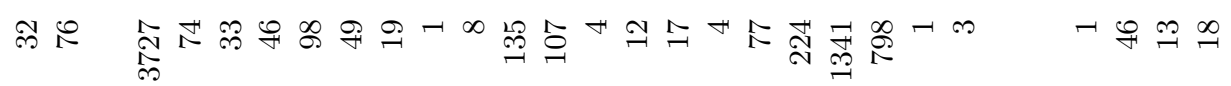

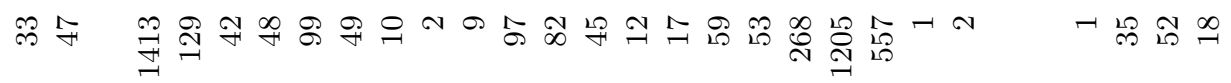

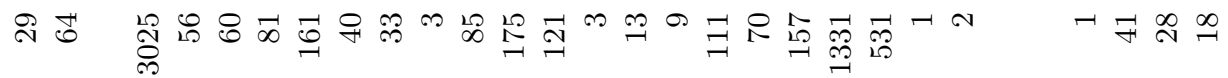

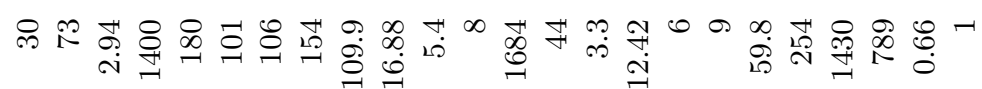

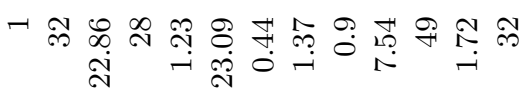

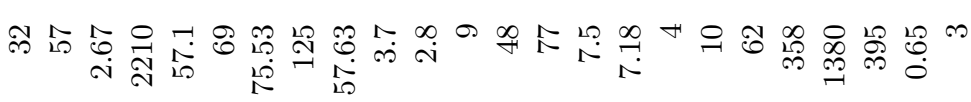

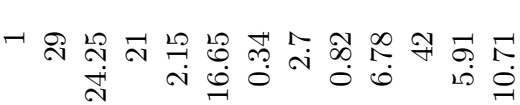




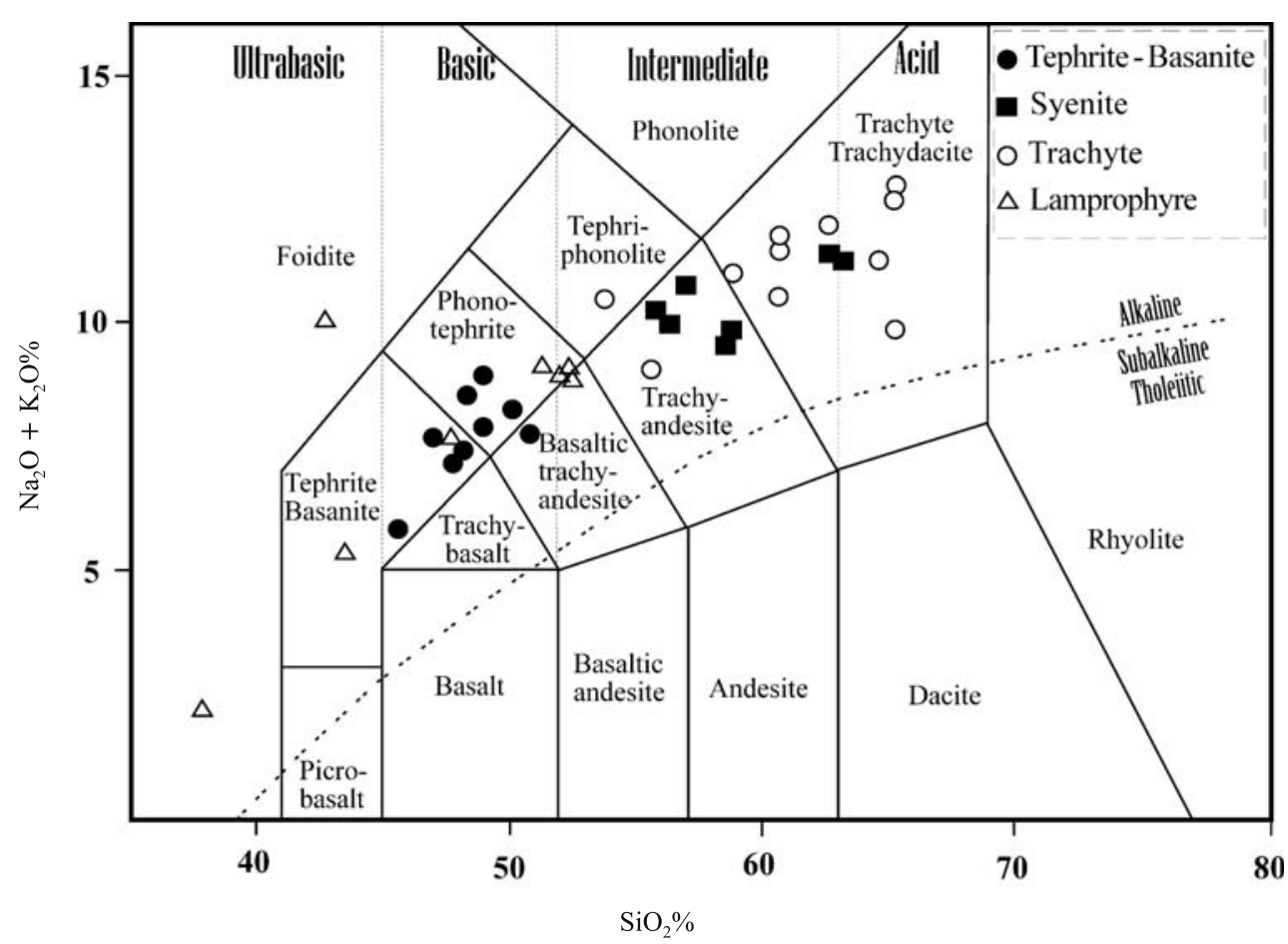

Figure 5. Rock types of Eslamy peninsula in TAS diagram after Le Bas et al (1986).
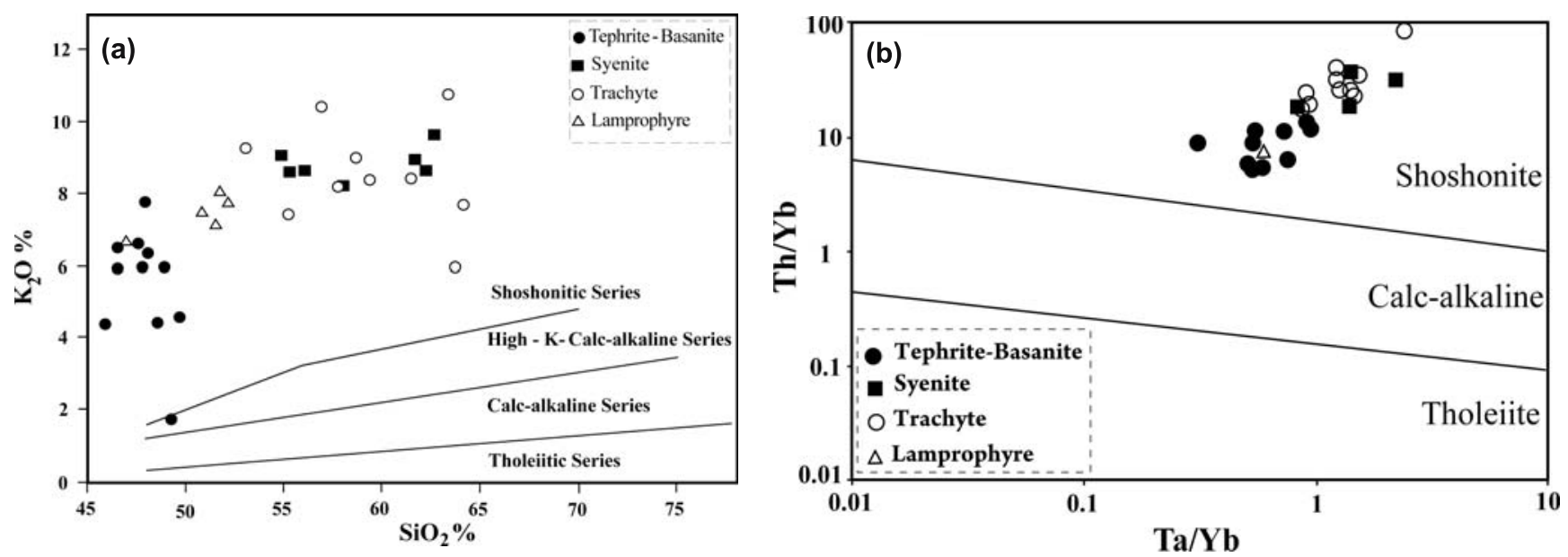

Figure 6. Eslamy peninsula rocks plot in the shoshonite field in diagram of $\mathrm{K}_{2} \mathrm{O}$ vs. $\mathrm{SiO}_{2}$ (after Peccerillo and Taylor 1976) and $\mathrm{Th} / \mathrm{Nb}$ vs. Ta/Yb (after Pearce 1983).

was used for major and trace element analyses. The amounts of major oxides and 27 elements were determined in these specimens as well. Furthermore, 14 specimens were selected for studying the behaviour of rare earth elements (REE). 33-element analyses were performed using Neutron Activation Analysis (NAA) method. A miniature neutron source reactor (MNSR) operating in $27 \mathrm{~kW}$ condition in Isfahan Nuclear Research Center was used for NAA. The error in the analyses was about $1 \%$. In addition to the above-mentioned samples, the results of analyses included 15 samples
(Moayyed et al 2008) were used for drawing the graphs and conclusions (table 2).

\section{Geochemistry}

Based on analytic data and the plot of alkalies vs. silica (TAS) of the old volcanism in Eslamy peninsula, the samples lie within the field of basalt, trachy-basalt, tephrite and phonotephrite. Samples representing young magmatic activities were plotted within the trachyte, trachyandesite, phonolite, 


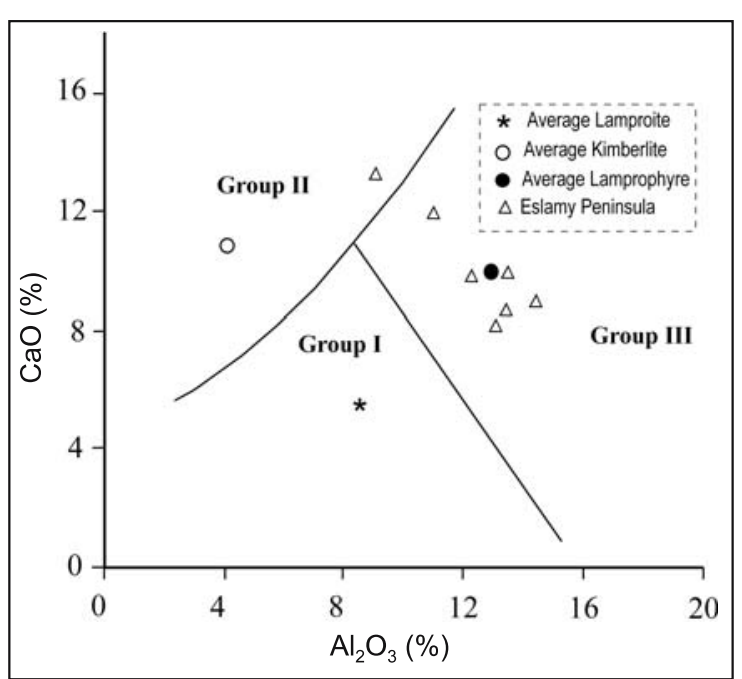

Figure 7. Eslamy rocks plot in the group III of potassic igneous rocks (after Foley et al 1987). trachyphonolite, syenite and syenodiorite fields and lamprophyre samples were represented in the foidite, tephrite and trachyandesite fields (figure 5).

In general, based on the $\mathrm{K}_{2} \mathrm{O} / \mathrm{SiO}_{2}$ diagram of Peccerillo and Taylor (1976) and the $\mathrm{Th} / \mathrm{Yb}-\mathrm{Ta} / \mathrm{Yb}$ diagram of Pearce (1983), the original magma of Eslamy peninsula rocks had a shoshonitic to ultrapotassic nature (figure $6 \mathrm{a}, \mathrm{b}$ ). The $\mathrm{K}_{2} \mathrm{O} / \mathrm{Na}_{2} \mathrm{O}$ ratio in tephritic and basanitic rocks is always higher than 1 , even reaching 4 at times. These rocks have normative olivines and leucites, rich in LILE and LREE. The above-mentioned qualities also exist in trachytes, phonolites, syenites and lamprophyres of the study area. In the $\mathrm{CaO} / \mathrm{Al}_{2} \mathrm{O}_{3}$ diagram of Foley et al (1987) the rock types of Eslamy peninsula plot in field III (Roman type rocks, figure 7). Geochemical investigation of minor and trace elements shows these rocks to be rich in LIL. This characteristic is
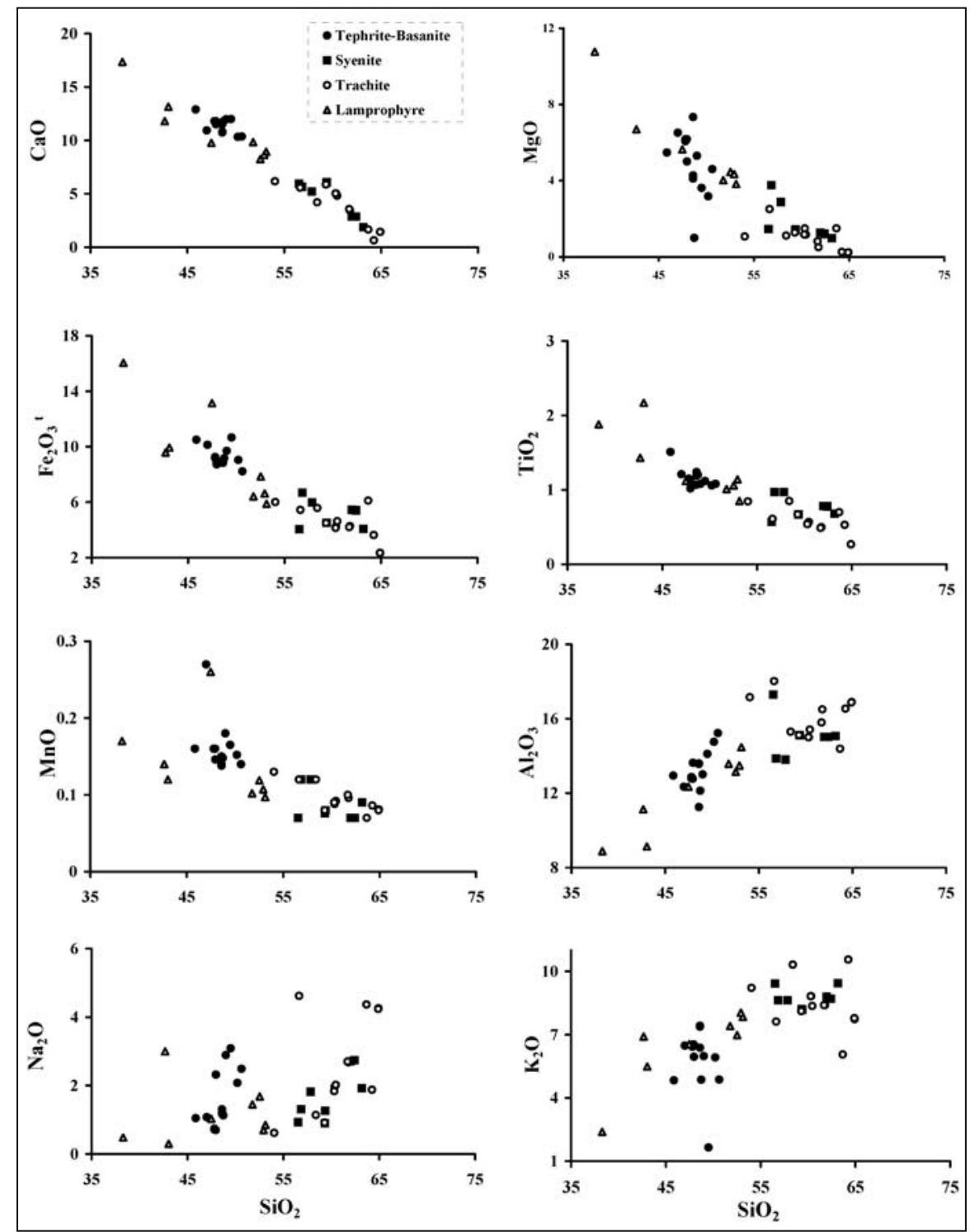

Figure 8. Harker variation diagrams for Eslamy peninsula rocks (after Harker 1909). 


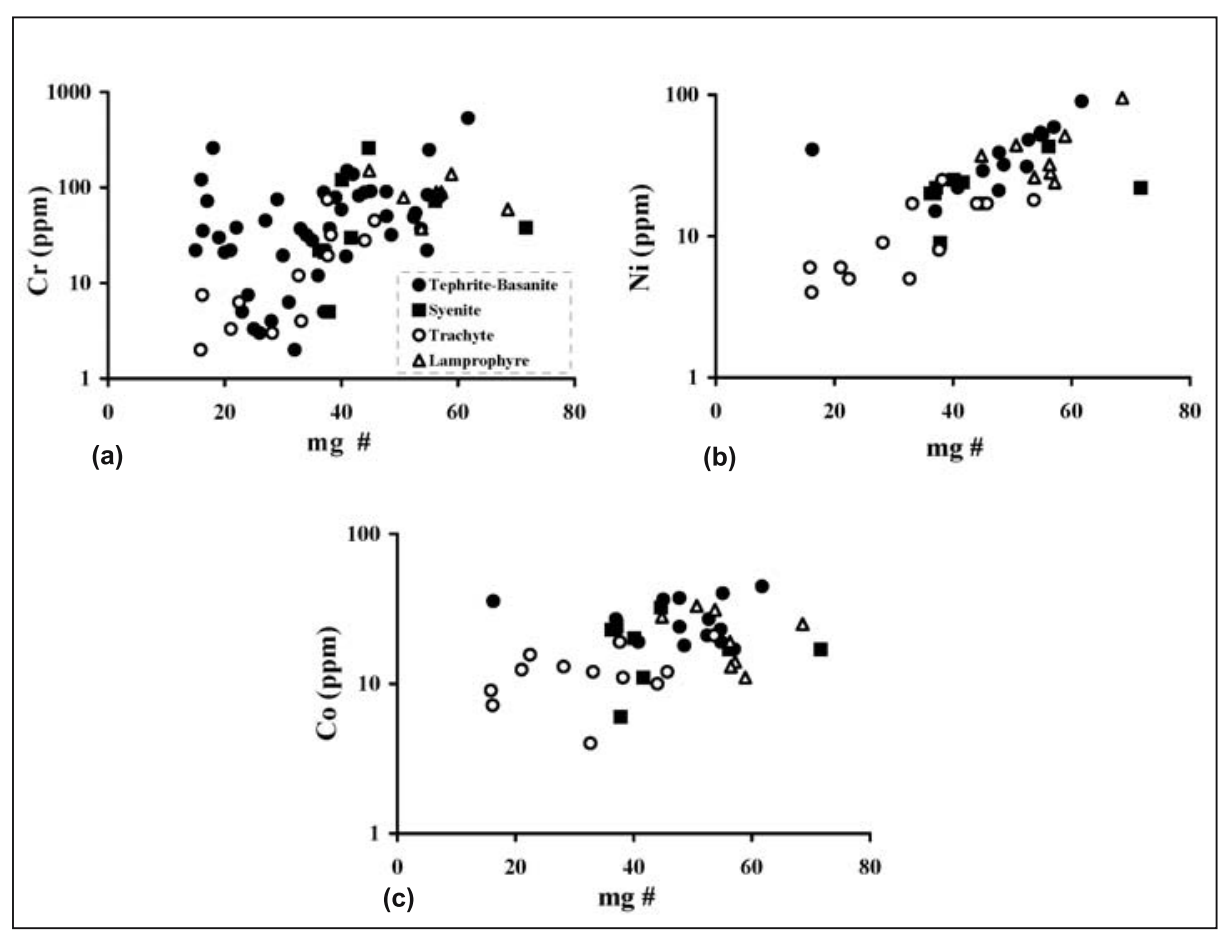

Figure 9. Eslamy peninsula rocks plot in variation diagrams (a) mg \#/Cr, (b) mg \#/Ni, and (c) mg \#/Co.

related to the role of liquid phases in magma generation (Rollinson 1993). Depletion of HFSE is an important feature in Roman type rocks that exist in Eslamy peninsula rocks.

Harker diagram was used for studying the major oxides vs. silica variations. Investigation of these diagrams showed that there is a geochemical similarity between all rock types of the peninsula (figure 8).

$\mathrm{CaO}, \mathrm{MgO}, \mathrm{Fe}_{2} \mathrm{O}_{3}, \mathrm{TiO}_{2}$ and $\mathrm{MnO}$ decrease with $\mathrm{SiO}_{2}$ increasing. The similarities between $\mathrm{TiO}_{2}$ and $\mathrm{Fe}_{2} \mathrm{O}_{3}$ decline in relation to ilmenite, magnetite and titanomagnetite crystallization. The sharp decline in $\mathrm{MgO}$ vs. silica (under $50 \%$ of silica) show olivine (in early stage) and diopside (in latter stages) crystallization. There is no distinctive variation for $\mathrm{K}_{2} \mathrm{O}$ and $\mathrm{Na}_{2} \mathrm{O}$ vs. silica. This case may indicate crustal contamination in Eslamy peninsula rocks. High amounts of $\mathrm{K}_{2} \mathrm{O}$ in mafic rocks reveal that crystallization of leucite has happened in dry conditions. Ca rich plagioclases are absent in Eslamy peninsula rocks so intense decreases in $\mathrm{CaO}$ and subsequent increases in $\mathrm{Al}_{2} \mathrm{O}_{3}$ was in relation to diopside crystallization. The replacement of iron by manganese in olivine and pyroxene caused a slow decrease in $\mathrm{MgO}$ vs. silica.

The investigation of $\mathrm{mg} \# / \mathrm{Ni}$ diagram showed the fractional crystallization of olivine in magma. Dispersion of samples in $\mathrm{mg} \# / \mathrm{Cr}$ and $\mathrm{mg} \# / \mathrm{Co}$ is responsible for crustal contamination (figure 9).

The ratio of $(\mathrm{Ba} / \mathrm{La})_{\mathrm{n}}$ and $(\mathrm{Th} / \mathrm{Nb})_{\mathrm{n}}$ in Eslamy peninsula rocks are between 1.29 to 10.95 and 3.35 to 23.06. These characteristics prove the crustal contamination on the petrogenesis of ultrapotassic rocks in Eslamy peninsula (Taylor and McLennan 1985). $\mathrm{Al}_{2} \mathrm{O}_{3} / \mathrm{TiO}_{2}$ ratio in the primitive mantle (PM) is about 27.75, in upper mantle it is 22 and the average of this ratio in Eslamy peninsula is $19.2(63.1-4.21)$, so this amount shows crustal contamination of magma that originated from the mantle. Thus the ratio of $\mathrm{Zr} / \mathrm{Nb}$ and $\mathrm{Rb} / \mathrm{Sr}$ is about 14.82 and 0.031 in the primitive mantle $(\mathrm{PM})$, but it is 9.09 and 0.123 in the continental crust (Taylor and McLennan 1985). Variations of $\mathrm{Zr} / \mathrm{Nb}$ and $\mathrm{Rb} / \mathrm{Sr}$ in Eslamy peninsula ratios are from 6.9 to 33.4 (10.8 average) and 0.06 to 1.92 (0.26 average). The low ratio of $\mathrm{Zr} / \mathrm{Nb}$ and high ratio of $\mathrm{Rb} / \mathrm{Sr}$ in relation to primitive mantle, point to the role of continental crust in Eslamy peninsula magmatism.

Scrutinizing the major and trace elements behaviour in the Eslamy peninsula rocks shows that fractional crystallization and segregation of olivine, clinopyroxene and leucite are the main factors controlling the evolution of the magmas. The existence of a large amount of leucite in basanites and tephrites reveals that the corresponding magmas are solidified in low water pressure or even in dry conditions. Probable contamination by crustal rocks and magma mixing were among the other factors in magmatic evolution of the studied rocks. High $\mathrm{Nb} / \mathrm{Ta}$ and $\mathrm{Zr} / \mathrm{Hf}$ ratios (Dupuy et al 1992; Rudnick et al 1993; Furman and Graham 1999; Foley et al 2002) in the lamprophyres studied 

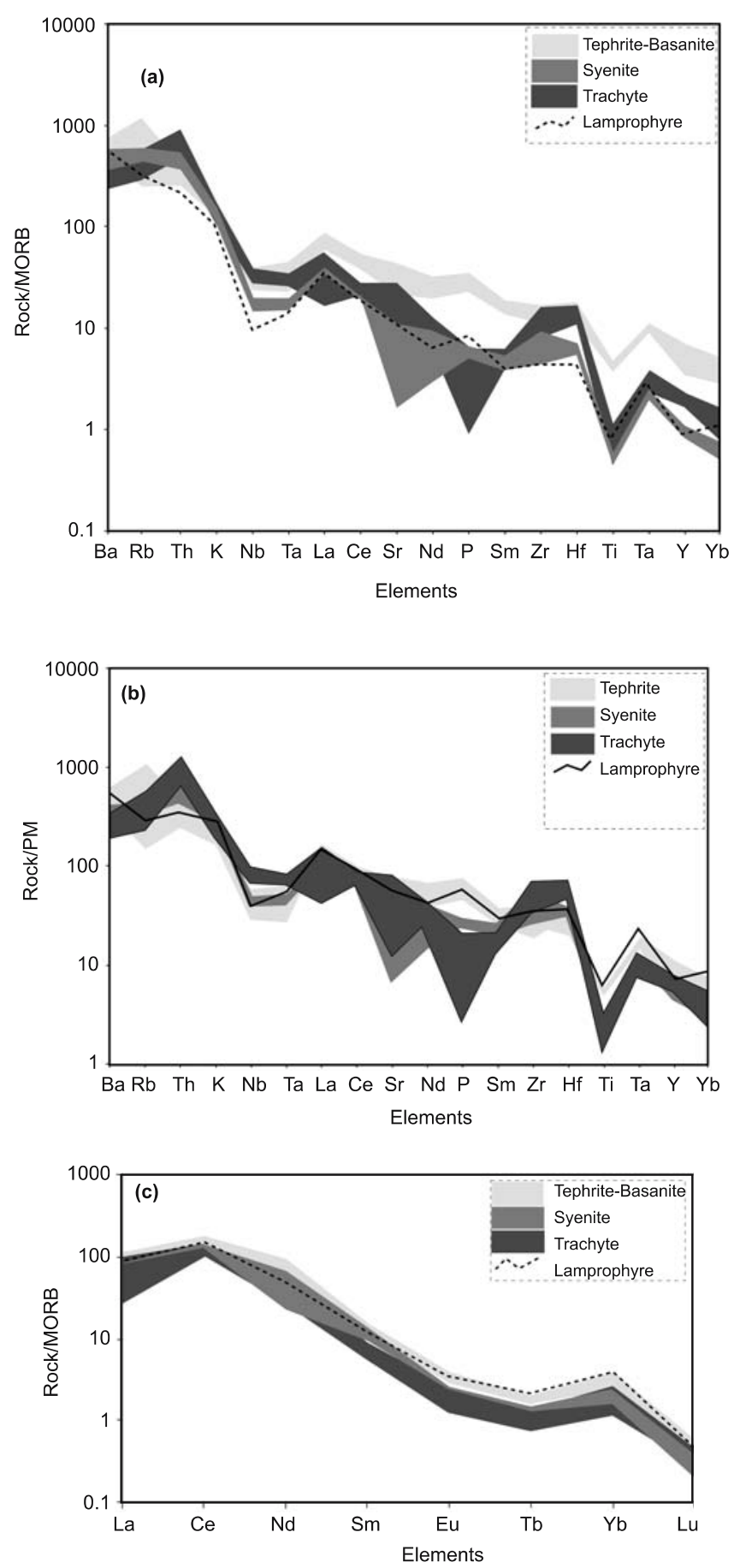

Figure 10. Spider diagrams normalized to the (a) MORB, (b) PM, and (c) REE pattern normalized to MORB (data for MORB and PM from Sun and McDonough 1989).

indicate enrichment process for the source region prior to partial melting and crustal contamination or differential crystallization (Moayyed et al 2008). The above-mentioned ratios are controlled by magmatic processes such as partial melting, crystallization and rutile and amphibole metasomatism in the mantle (Ionov et al 1997; Foley et al 2000, 2002; Tiepolo et al 2001). High REE/HFSE ratio for the Eslamy lamprophyres such as high $\mathrm{Eu} / \mathrm{Ti}$ may indicate a carbonatitic metasomatism as well. Non-existence of negative anomaly for $\mathrm{Eu}$ shows that the mechanism of fractional crystallization and plagioclase separation does not play any significant role in Eslamy peninsula magmatism. High amounts of Th and U in the Eslamy rock units show possible contamination by the middle to upper crust (Taylor and McLennan 1985). To elucidate the nature of the Eslamy peninsula lamprophyres, they are compared with typical alkaline (Spanish Central System) and calc-alkaline lamprophyres (Orejana et al 2006).

The study of spider diagrams which were plotted for REE and normalized to MORB and PM indicates that these elements have the same behaviour in basic, intermediate and acidic rocks of the peninsula and display a general negative slope (figure 10a, b, c). This characteristic suggests a co-magmatic origin for the studied rocks and also is demonstrative of great depth and a high $\mathrm{CO}_{2} / \mathrm{H}_{2} \mathrm{O}$ ratio. Most of these features are attributed to the origin of these rocks from a metasomatised mantle (Guo et al 2004). The absence of amphibole in peninsula rocks can explain the negative anomaly for HREE (Rollinson 1993). The positive anomaly for Th, Rb, $\mathrm{K}$ and $\mathrm{Ba}$, is similar to Roman type and may reflect crustal contamination in magma evolution and low ratio melting in enriched mantle (Taylor and McLennan 1985; Wilson 1989; Rollinson 1993).

The negative anomaly for $\mathrm{Ta}, \mathrm{Nb}$ and $\mathrm{Ti}$ can show the role of subducted liquids in mantle metasomatism (Rollinson 1993). The negative anomaly of $\mathrm{P}$ in peninsula is an important index for high potassic post collision rocks (Muller and Groves 1997).

\section{Geodynamic environment}

Tectonic setting of the shoshonitic and ultrapotassic rocks of the Eslamy peninsula were investigated using the diagram proposed by Muller and Groves (1997) (figure 11) and it was deduced that potassic and ultrapotassic magmatism of the Eslamy peninsula has occurred in a post-collision magmatic arc (figure 11).

This study shows that, despite the former models for magmatism in the Eslamy peninsula, this geological event is neither related to subduction of Neo-Tethys beneath the central Iranian plate, nor did it occur in a continental rift zone. It could be suggested that the combination of fault displacements and their trend distribution relative to the maximum stress applied to the studied area, had an important role in post-collision magmatism of the Eslamy peninsula. Evidence to 


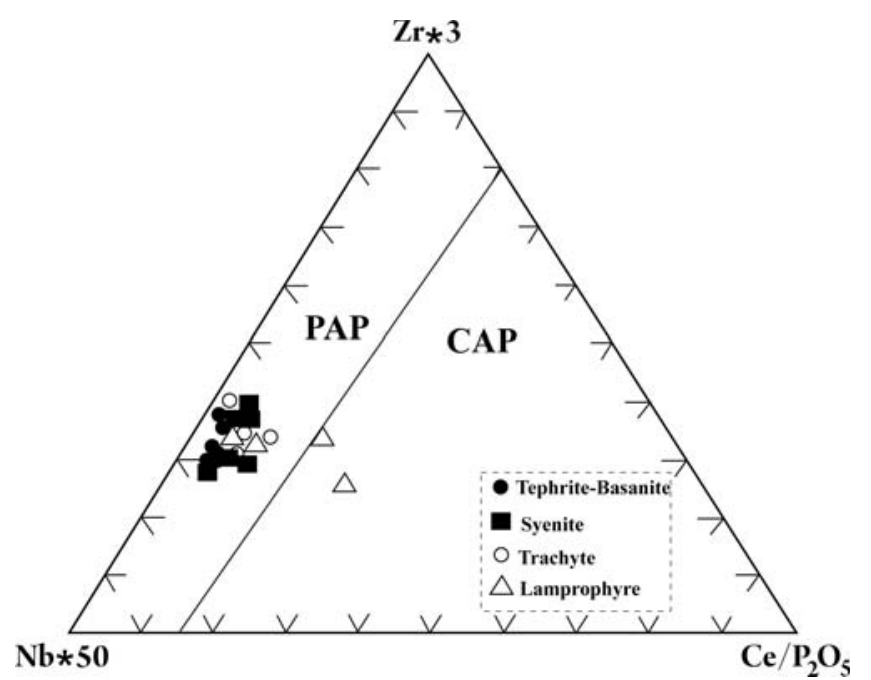

Figure 11. $\mathrm{Ce} / \mathrm{P}_{2} \mathrm{O}_{5}-\mathrm{Nb}^{*} 50-\mathrm{Zr}^{*} 3$ diagram for separation of potassic rocks interrelation with post collision arc (PAP) and active continental margin (CAP) after Muller et al (1992) with position of Eslamy peninsula rocks.

suggest this can be found in the fact that there are a large number of fault systems in the central Iranian block and in the northwest of Iran and also considering the oblique pressure due to the convergence of the Iranian continental crust and the Arabian plate. The fore-mentioned having been caused by the spreading of the Red Sea.

\section{Conclusions}

Eslamy peninsula is a complex stratovolcano with a collapsed caldera which is intruded by later lamprophyres, trachytes, phonolites and syenites. The older magmatic activities include tephrite, basanite and the related pyroclastic rocks whereas the younger events tend to be acidic terms.

Sieve texture and normal zoning in clinopyroxenes and the existence of abundant amounts of leucites in tephritic and basanitic lavas demonstrate that magma mixing, assimilation followed by a quick pressure decrease during ascent were the main factors in the evolution of relatively dry magmas of the Eslamy peninsula.

The magmas that produced rocks of the peninsula must have had a shoshonitic to ultrapotassic nature (Roman type) and had most likely been generated from partial melting of garnet lherzolitic mantle with low partial melting ratio in a high $\mathrm{CO}_{2} / \mathrm{H}_{2} \mathrm{O}$ condition, probably. Investigation of Harker diagrams showed that there is a geochemical similarity between all rock types of Eslamy peninsula. These magmas are presumed to have been contaminated by crustal materials during rising up toward the surface. Variation of $\mathrm{K}_{2} \mathrm{O}$,
$\mathrm{Na}_{2} \mathrm{O}$ vs. silica and $\mathrm{mg} \neq / \mathrm{Cr}$, Co and the ratios of $(\mathrm{Ba} / \mathrm{La})_{\mathrm{n}},(\mathrm{Th} / \mathrm{Nb})_{\mathrm{n}}, \mathrm{Al}_{2} \mathrm{O}_{3} / \mathrm{TiO}_{2}, \mathrm{Zr} / \mathrm{Nb}$ and $\mathrm{Rb} / \mathrm{Sr}$ show the crustal contamination in Eslamy peninsula rocks. Fractional crystallization of olivine, diopsidic clinopyroxene and leucite played an important role in the evolution of magmas.

Existence of a large amount of leucite in basanites and tephrites reveals that the corresponding magmas are solidified in low water pressure or even dry conditions. High REE/HFSE ratio for the Eslamy lamprophyres such as high $\mathrm{Eu} / \mathrm{Ti}$ may indicate a carbonatitic metasomatism as well.

Spider diagrams of REEs imply that all rocks in peninsula are co-magmatic and general negative slope along with high LREE and low HREE anomalies suggest for a garnet lherzolite source and partial melting in high $\mathrm{CO}_{2} / \mathrm{H}_{2} \mathrm{O}$ conditions. LREE concentrations in the lamprophyre dykes and plugs reflect the existence of garnet as a residue of the melting (Polat et al 1997). The negative anomaly for $\mathrm{Ta}, \mathrm{Nb}$ and $\mathrm{Ti}$ can show the role of subducted liquids in mantle metasomatism.

Shoshonitic and ultrapotassic magmatism of Eslamy peninsula is supposed to have occurred in a post-collisional tectonic setting (Muller and Groves 1997) without any relation to Neo-Tethyan subduction or continental rifts.

\section{Acknowledgements}

The authors would like to thank the Payame Noor University for financial support. We are thankful to Dr A A Clagari, Dr M Moazzen, M Hoseinpour and M Hajialilu for their valuable suggestions.

\section{References}

Amidi S M 1975 Contribution a' L'etude stratigraphique, P'etrologique, et P'etrochimique des roches magmatiques de la re'gion de Natanz-Nain-Surlc (Iran Central); The'se. Doct. Etat, Grenoble.

Amidi S M, Emami M H and Michel R 1984 Alkaline character of Eocene volcanism in the middle part of central Iran and its geodynamic situation; Geologicshe Rundschau $\mathbf{7 3}$ 917-932.

Berberian F 1981 Petrogenesis of Iranian plutons; a study of the Natanz and Bazman intrusive complex; Ph.D. thesis, University of Cambridge, 300p.

Berberian F and Berberian M 1981 Tectono-plutonic episodes in Iran, in Zagros, Hindukush, Hymalaya, geodynamic evolution. In: (eds) Gupta $\mathrm{H}$ and Delany F, American Geophysical Union, Geodynamics Series 3 5-32.

Dehgani G A and Makris J 1983 The gravity field and crustal structure of Iran. In: Geodynamic project (Geotraverse) in Iran; Geol. Surv. Iran, Report. 51 $51-68$.

Dupuy C, Liotard J M and Dostal J 1992 Zr/Hf fractionation in intraplate basaltic rocks: carbonate metasomatism in the mantle source; Geochim. Acta 56 2417-2423. 
Emami M H 1981 Geologie de la regim de Qom-Aran (Iran), Contribution a' l'etude dynamique et geochimique du volcanisme tertiaire de l' Iran central; These d'Etat. Univer. Grenoble, France.

Foley S F, Tiepolo M and Vannucci R 2002 Growth of early continental crust controlled by melting of amphibolite in subduction zones; Nature 417 837-840.

Foley S F, Barth M G and Jenner G A 2000 Rutile/melt partition coefficient for trace elements and assessment of the influence of rutile on the trace element characteristics on the subduction zone magmas; Geochim. Cosmochim. Acta 64 629-638.

Foley S F, Venturelli G, Green D H and Toscani L 1987 The ultra-potassic rocks: characteristics, classification and constraints for petrogenetic models; Earth Sci. Rev. 24 81-134.

Furman T and Graham D 1999 Erosion of lithospheric mantle beneath the east African rift system: Geochemical evidence from the Kivu volcanic province; Lithos $\mathbf{9 8}$ 237-262.

Guo F, Fan W, Wang Y and Zhang M 2004 Origin of early cretaceous calc-alkaline lamprophyres from the Sulu orogen in eastern China: Implications for enrichment processes beneath continental collisional belt; Lithos $\mathbf{7 8}$ 291-305.

Hajalilou B 2005 Investigation of mineral resources in alkaline rocks from Islamy peninsula in Urmia lake, 3MA, Morocco.

Hajalilou B 2006 Metallic and nonmetallic mineralization in shoshonitic rocks, 5th European Congress on Regional Geoscientific Cartography and Earth Information Systems, Barcelona, Spain.

Hajalilou B and Moayyed M 2005 Petrography and petrology of the alkaline potassic rocks from Islamy peninsula, NW of Iran and their geodynamic environment, EGU, Austria.

Harker A 1909 The natural history of igneous rocks. London, Huen, $383 \mathrm{p}$

Harris P G 1957 Zone refining and the origin of potassic basalts; Geochim. Cosmochim. Acta 12 195-208.

Ionov D A, O' Reilly S Y and Griffin W L 1997 Volatile bearing minerals and lithophile trace elements in the the upper mantle; Chem. Geol. 141 153-184.

Key R W and Gast P W 1973 The rare earth content and origin of alkali-rich basalts; J. Geol. 81 653-682.

Le Bas M J, Le Maitre R W, Strekeisen A and Zanettin B 1986 A chemical classification of volcanic rocks based on the total alkali silica diagrams; J. Petrol. 27 745-750.

Menzies M A and Hawkes C J 1981 Mantle metasomatism; Academic Press, London, 472pp.

Moayyed M, Moazzen M, Calagari A A, Jahangiri A and Modjarrad M 2008 Geochemistry and petrogenesis of lamprophyric dykes and the associated rocks from Eslamy peninsula, NW Iran: Implication for deep mantle metasomatism; Chemie der Erde Geochemistry 68 141-154.

Moine-Vaziri H 1985 Volcanisme tertiaire et quaternaire en Iran; These d'Etat Univer., Paris-Sud, Orsay.

Moine-Vaziri H, Khalili-marandi S H and Brousse R 1991 Importance d'un Volcanisme potassique, au miocene Superier en Azerbaidjan (Iran); C.R. Acad. Sci. Paris, t.313.Serie II 1603-1610.

Moradian-Shahrbabaky A 1997 Geochemistry, geochronology, and petrology of feldspatoid-bearing rocks in the
Urumieh-Dokhtar volcanic belt, Iran; Ph.D. thesis, University of Wollongonge, 411p.

Moradian-Shahrbabaky A 2007 Geological Setting and Geochronology of some alkalic and calc-alkalic rocks in western (Sary peninsula) and central (Soruk) UrmiehDokhtar Volcanic Belt, Iran; Earth \& Life 2(3) 6-24.

Morrison G W 1980 Characteristic and tectonic setting of the shoshonitic rock association; Lithos 13 97-108.

Muller D, Rock N M S and Groves D I 1992 Geochemical discrimination between shoshonitic and potassic volcanic rocks from different tectonic setting: A pilot study; Mineral. Petrol. 46 259-286.

Muller D and Groves D I 1997 Potassic igneous rocks and associated gold-copper mineralization; Sec.Updated. Springer-Verlag, 242pp.

Orejana D, Villaseca C and Paterson B A 2006 Geochemistry of pyroxenitic and hornblenditic xenoliths in alkaline lamprophyres from the Spanish Centeral System; Lithos 88 167-196.

Pearce J A 1983 The role of sub-continental lithosphere in magma genesis at destructive plate margins; In: Continental Basalts and Mantle Xenoliths (eds) Hawkesworth C J and Norry M J, Shiva, Nantwich, pp. 230-249.

Peccerillo A 1992 Potassic and ultrapotassic rocks: Compositional characteristics, petrogenesis and geologic significance; IUGS Episods 15 243-251.

Peccerillo A and Taylor S R 1976 Geochemistry of Eocene calc-Alkaline volcanic rocks from the Kastamonu area, northern Turkey; Contrib. Mineral. Petrol. 58 63-81.

Polat A, Kerrich R and Casey J F 1997 Geochemistry of Quaternary basalts erupted along the east Anatolian and Dead Sea fault zones of southern Turkey: Implication for mantle sources; Lithos 40 55-68.

Rittman A 1933 Die geologisch beding Te evolution and differentiation des somma-vesuv Magmas; Zeitsch fur vulkanol 15 8-94.

Rock N M S 1991 Lamprophyres. Blackie, Glasgow, 285p.

Rollinson H R 1993 Using geochemical data: Evalution, Presentation, Interpretation, Longman Scientific and Technical, England, 352p.

Roy A, Sarkar A, Jeyakumar S, Aggrawal S K, Ebihara M and Satoh H 2004 Late archaean metasomatism below eastern Indian craton. Evidence from trace element, REE geochemistry and Sr-Nd-O isotop systematics of ultramafic dykes; J. Earth Syst. Sci. 113(4) 649-665.

Rudnick R L, Mc Donough W F and Chapell B W 1993 Carbonatite metasomatism in the northern Tanzanian mantle: Petrographic and geochemical characteristics; Planet. Sci. Lett. 114 463-475.

Sun S S and McDonough W F 1989 Chemical and isotopic systematic of oceanic basalts: Implication for mantle composition and processes; In: Magmatism in the ocean basins (eds) Saunder A D and Norry M J, Geol. Soc. Spec. Publ. 42 313-345.

Taylor S R and McLenan S M 1985 The continental crust: Its composition and evolution, Blackwell, Oxford University Press, 312pp.

Tiepolo M, Bottazzi P, Foley S F, Orbeti R, Vannucci R and Zannetti A 2001 Fractionation of $\mathrm{Nb}$ and Ta from $\mathrm{Zr}$ and $\mathrm{Hf}$ at mantle depth: The role of titanian-pargasite and Kaersutite, J. Petrol. 42 221-232.

Wilson M 1989 Igneous petrogenesis a global tectonic approach; Unwin Hyman Ltd, London, 466p. 